\title{
COURSE OF INFECTION AND HISTOPATHOLOGICAL LESIONS IN MICE INFECTED WITH SEVENTEEN TrYpanosoma cruzi STRAINS ISOLATED FROM CHRONIC PATIENTS ${ }^{1}$
}

\author{
B R Schlemper $\mathrm{Jr}^{2}, \mathrm{C} M$ Ávila $^{3}, \mathrm{~J} \mathrm{R}$ Coura ${ }^{4}, \mathrm{Z}$ Brener $^{4}$
}

\begin{abstract}
Mice were infected with blood forms of 17 Trypanosoma cruzi strains recent/y isolated from chronic patients, which were classified as of low, medium or high virulence on grounds of the prepatent period, parasitemia and mortality at the acute phase. A total of 212 mice were studied after 3, 6, 9 and 12 months of infection. In the chronic phase, intracellular parasites were detected in $11.0 \%, 27.9 \%$ and $54.0 \%$ of mice inoculated, respectively, with the low, medium and high virulent strains $(r=0.98, p<0.005)$. Heart fibrosis was also related to virulence, affecting $5.7 \%, 11.6 \%$ and $30.8 \%(r=0.98, p<0.001)$ of the mice inoculated with the above strains; a similar relationship was observed between intensity and frequency of the heart inflammatory reaction and the severity of infection at its early stage. Necrotizing arteritis was detected in $12.2 \%$ of the inoculated animals and this lesion was related to the infection duration rather than to strain characteristics. Inflammatory lesions and tissue parasitism were stable within the period of observation. whereas fibrosis was progressive. The findings suggest that mice may reproduce heart lesions resembling human pathology and that organ damage apparently depends on the parasite virulence.
\end{abstract}

(Key words: Trypanosoma cruzi. Strains. Histopathology. Mouse).

An experimental chronic model of Chagas' disease in which the lesions resemble the pathology present in Trypanosoma cruzi infected humans would be highly desirable for immunopathological and related studies. Dogs chronically infected with $T$. cruzi may display mild focal chronic myocarditis with scarce fibrosis, which is characteristic of the indeterminate form of Chagas' disease. However, the development of the typical myocardiopathy is often unpredictable and may occur in only a few animals. Rabbits have been described as a suitable chronic model by Teixeira et al. ${ }^{18}$ but the results are still controversial despite recent findings confirming the occurrence of typical heart lesions in this host ${ }^{13}$.
Mice could be very useful models for chronic Chagas' disease because of their availability, low maintenance costs, handling facility and the possibility of working with animals of known genetic background. Infiltrates of mononuclear cells, fibrosis and neuronal destruction have been reported in chronically infected mice ${ }^{2}$. Recently, histopathological lesions and electrocardiographic changes resembling those found in the human cardiopathy were described in T. cruzi infected mice ${ }^{11}$. Nevertheless, a more precise standardisation of this model is still needed, chiefly in aspects related to the influence of parasite strains and the course of infection. In this paper we studied the progressive aspects of the chronic lesions induced in

( ${ }^{1}$ Supported by the National Research Council, Brasil.

$\left(^{2}\right)$ Universidade Federal de Santa Catarina, $\left(^{3}\right)$ Universidade Federal do Rio de Janeiro, $\left(^{4}\right)$ Fundação Oswaldo Cruz, Brasil.

Recebido para publicação em 29/12/82 
mice by $17 T$. cruzi strains isolated from chronic patients, as well as the role played by the parasite virulence in the pathogenesis of the disease.

\section{MATERIAL AND METHODS}

T. cruzi "strains". The parasite strains were isolated by xenodiagnosis performed in patients using 40 nymphs of Triatoma infestans. Metacyclic trypomastigotes were collected from the faeces and urine of positive insects ${ }^{19}$ and inoculated into normal and X-irradiated $(500 \mathrm{r}$ ) mice by the intraperitoneal route. Further serial blood passages were carried out, according to the characteristics of the established infections, in variable periods of time between 15 and 30 days, using normal mice. The number of passages of the strains in mice before utilization in the experiments ranged from 1 to 10 but, in most instances, the parasites were used after 7 to 9 serial passages. Of the seventeen strains used, eleven (VL-1 to $V L-11)$ were isolated from patients living in Virgem da Lapa and six $(\lg -1$ to $\lg \cdot 6)$ in Iguatama, both endemic areas in the State of Minas Gerais, Brasil. The strains had been isolated from patients with different chronic clinical forms of Chagas' disease, namely, 9 of indeterminate, 2 of cardiac, 3 of digestive and 2 of cardiac plus digestive forms. The isoẹnzyme patterns determined in 10 strains from Virgem da Lapa and 3 from Iguatama ${ }^{15}$ showed that all of them were equivalent to zymodeme a' of Miles et al. ${ }^{12,14}$. Male albino outbred mice weighing 15 - 18g were used. In some experiments $\mathrm{C} 3 \mathrm{H}$ male mice of the same weight were also used.

Course of the acute infection. Groups of 7 to 9 mice were inoculated by the intraperitoneal route with $5 \times 10^{3}$ bloodstream forms of the different strains. The parasitemia was determined according to Brener ${ }^{5}$. The prepatent period and the curves of parasitemia were determined by daily bloodexamination performed during the first days of infection and, afterwards, by counting parasites every 3 to 4 days until the 50 th day of infection. Mortality rates were recorded daily.

Studies of the chronic phase. Groups of $20-25$ mice were inoculated by the intraperi. toneal route with bloodstream forms of all 17 strains. In 12 groups the animals received ino cula of $5 \times 10^{3}$ parasites; in 4 groups, $1 \times 10^{4}$ parasites and, finally, in one group. $2 \times 10^{4}$ blood forms. Groups of uninfected mice of the same age and sex were used as controls. The animals were killed usually 90 and 180 days after infection; in some experiments, infected and control animals were kept in the laboratory for 270 and 365 days, and then killed. Fragments of the following organs and tissues were collected and fixed in 10\% formaldehyde: heart (in totum), esophagus, small intestine, colon, liver, spleen and skeletal muscle (triceps). From each fragment and from the whole heart three histological sections of $5 \mu \mathrm{m}$ separated by $20 \mu \mathrm{m}$ intervals were obtained. The sections were stained by hematoxylin-eosin as well as by the method of Masson for the specific study of fibrosis. The histological preparations were coded and then examined for parasitism and lesions.

Statistical analysis. Linear regression was used to establish correlations whereas the Chisquared $\left(X^{2}\right)$ test was used to estimate significance.

\section{RESULTS}

Course of the acute phase. The analysis of the course of infection in the various groups of mice inoculated with the different strains permitted to differentiate them into: Group $\mathrm{I}$, including strains VL-1, VL-5, VL-6, VL-8, $\lg -1, \lg -2, \lg -3, \lg -4$ and $\lg -5$. The virulence of these strains was low and they induced infections in mice with a long prepatent period (11 to 30 days), the highest parasitemia occurring between 21 and 40 days of infection with a maximum of $10^{5}$ parasites $/ \mathrm{ml}$. All animals survived the acute phase, with the exception of the group inoculated with the VL-6 strain which killed $12 \%$ of the mice. Group II, including strains of intermediate virulence (VL-2, VL-3, VL-4, VL-7, VL-9 and $V L-11)$. The prepatent period was shorter (8 to 18 days), the peaks of parasitemia were detected between 23 and 29 days of infection, and the number of blood parasites at this time reached $6 \times 10^{5} / \mathrm{ml}$. The animals also survived the acute phase but, conversely to what was observed with the strains of group I, mortality could be induced by increasing the number of blood forms in the inocula. Group III, with two high virulent strains (VL-10 and Ig-6). The prepatent period was rather short (6 to 12 days).

the parasitemia was increasingly ascendent 


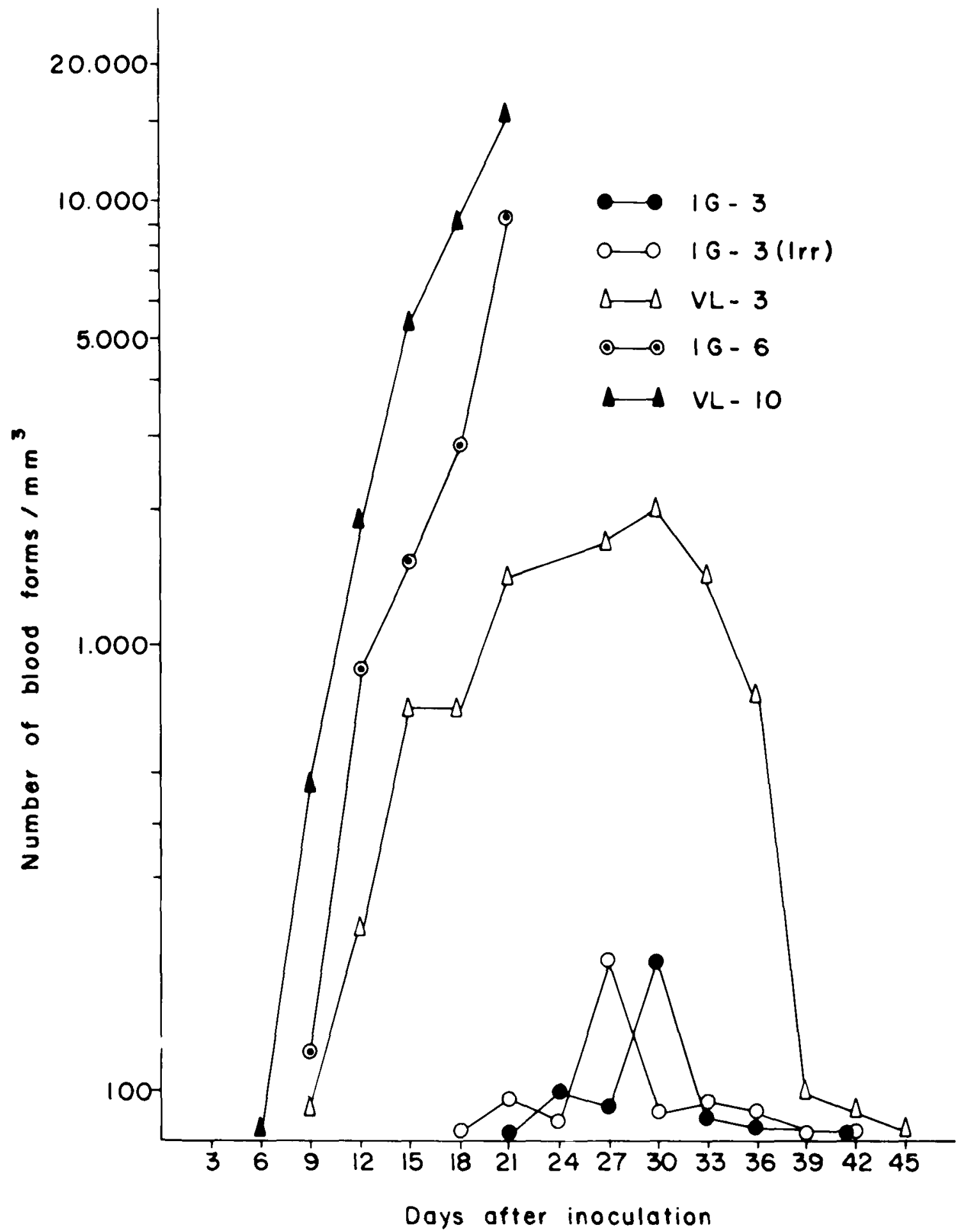

Fig. 1 - Curves of parasitemia in groups of mice inoculated with 5.000 bloodstream trypomastigotes of $T$. cruzi strains of low $(\lg -3, \lg -3$ (rr.), intermediate (VL-3) and high virulence $(\mathrm{lg}, 6, V L-10)$. In the experiment performed with Ig-3 $(\mid \mathrm{rr}$.$) the parasites was inoculated into immunosuppressed X$-irradiated mice. 


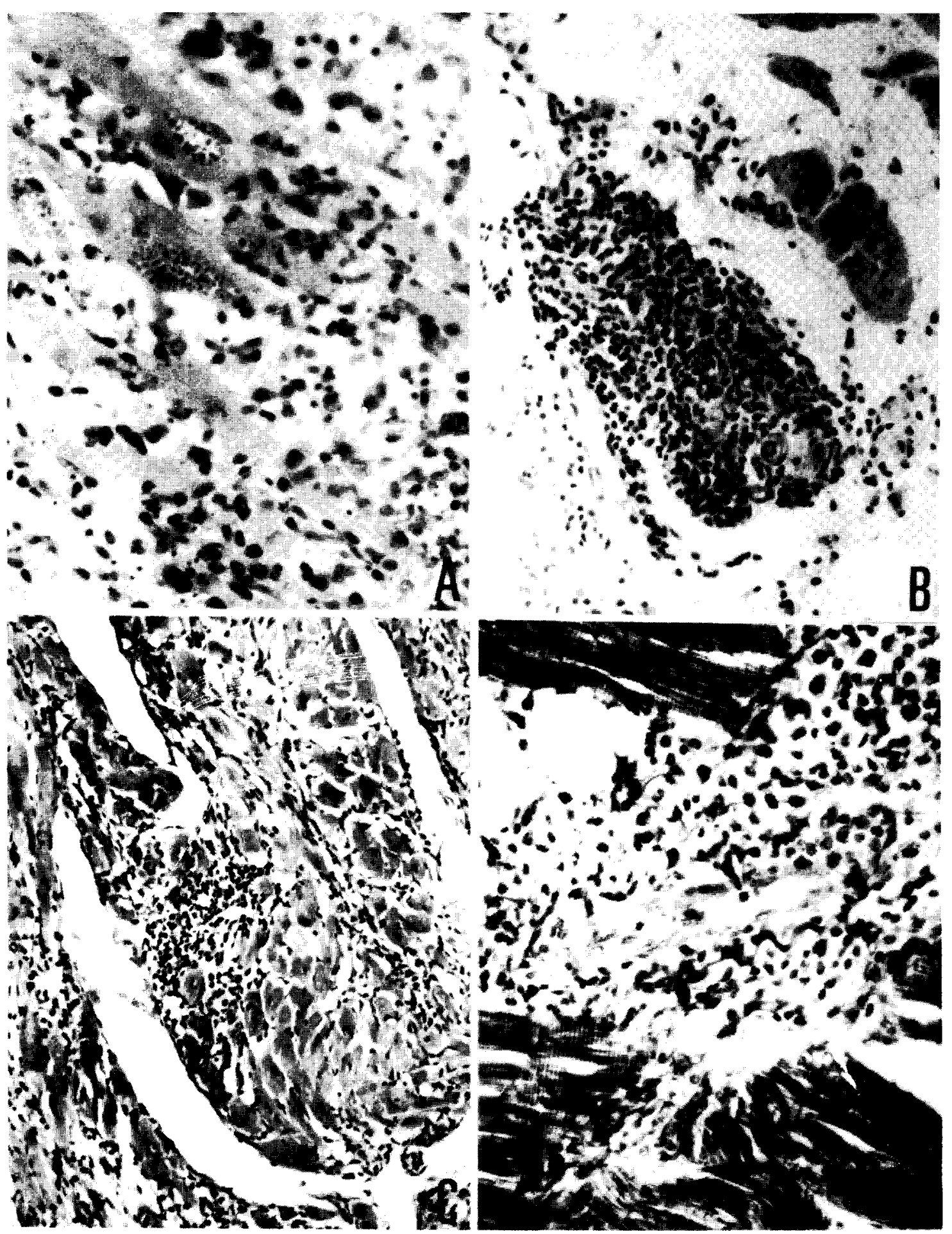

Fig. 2 - A: Strain VL-10, acute phase, 20 days of infection. Heart with infiltrates of inflamatory cells, predominantly mononuclears. Parasitism of muscle cells $(320 X)$; B: Strain VL-10, chronic phase, 90 days of infection. Inflammatory process in an intracardiac neuron ganglia and destruction of neuron cells (200X); C: Strain VL-10, chronic phase, 180 days of infection. Chronic myocarditis with monocuclear inflammation (150X); D: Strain VL-10, chronic phase, 180 days of infection. Destruction of skeletal muscle cells with mononuclear infiltrate $(320 X)$. 


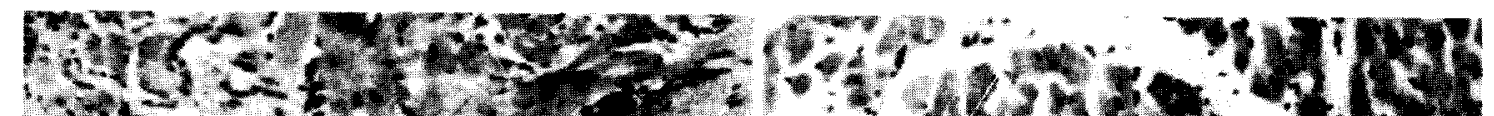

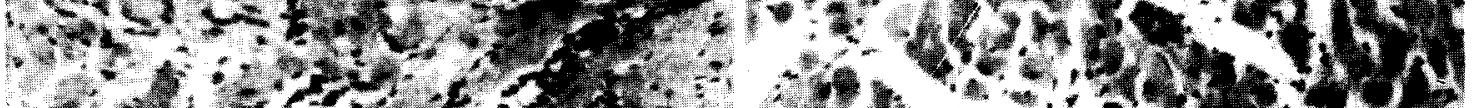

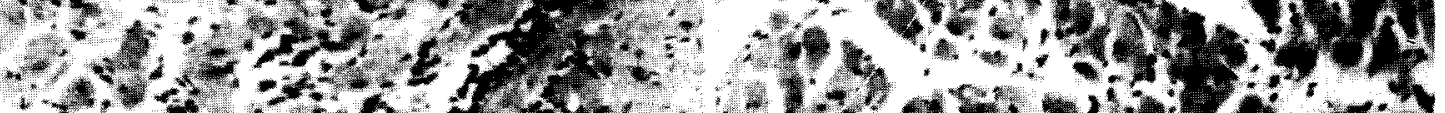
-

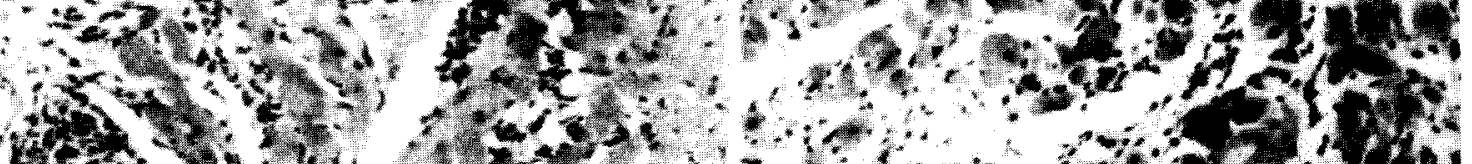

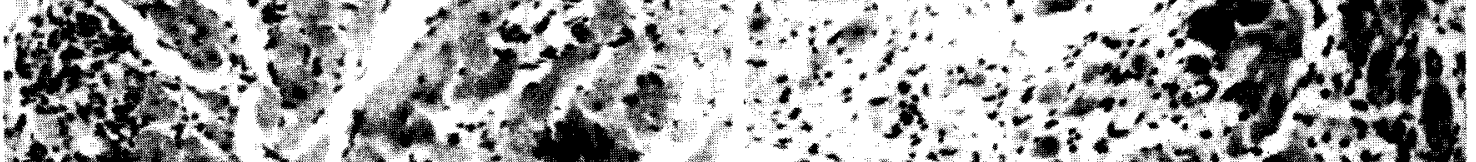

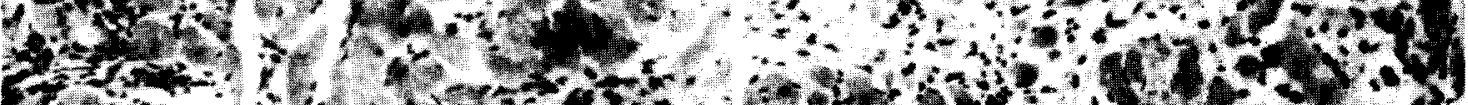

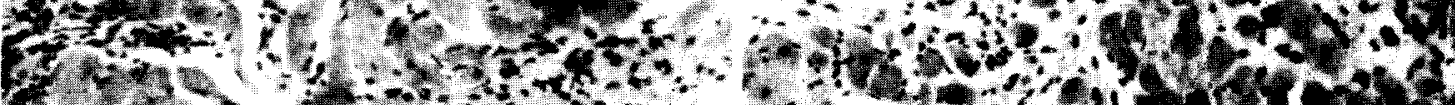
Fy

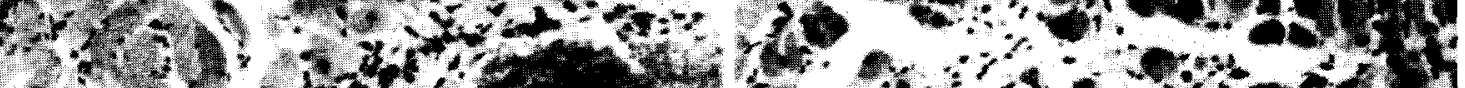

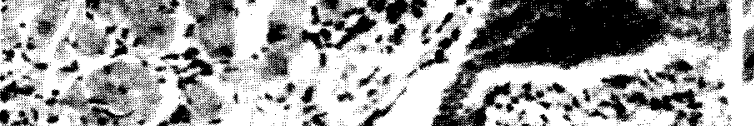
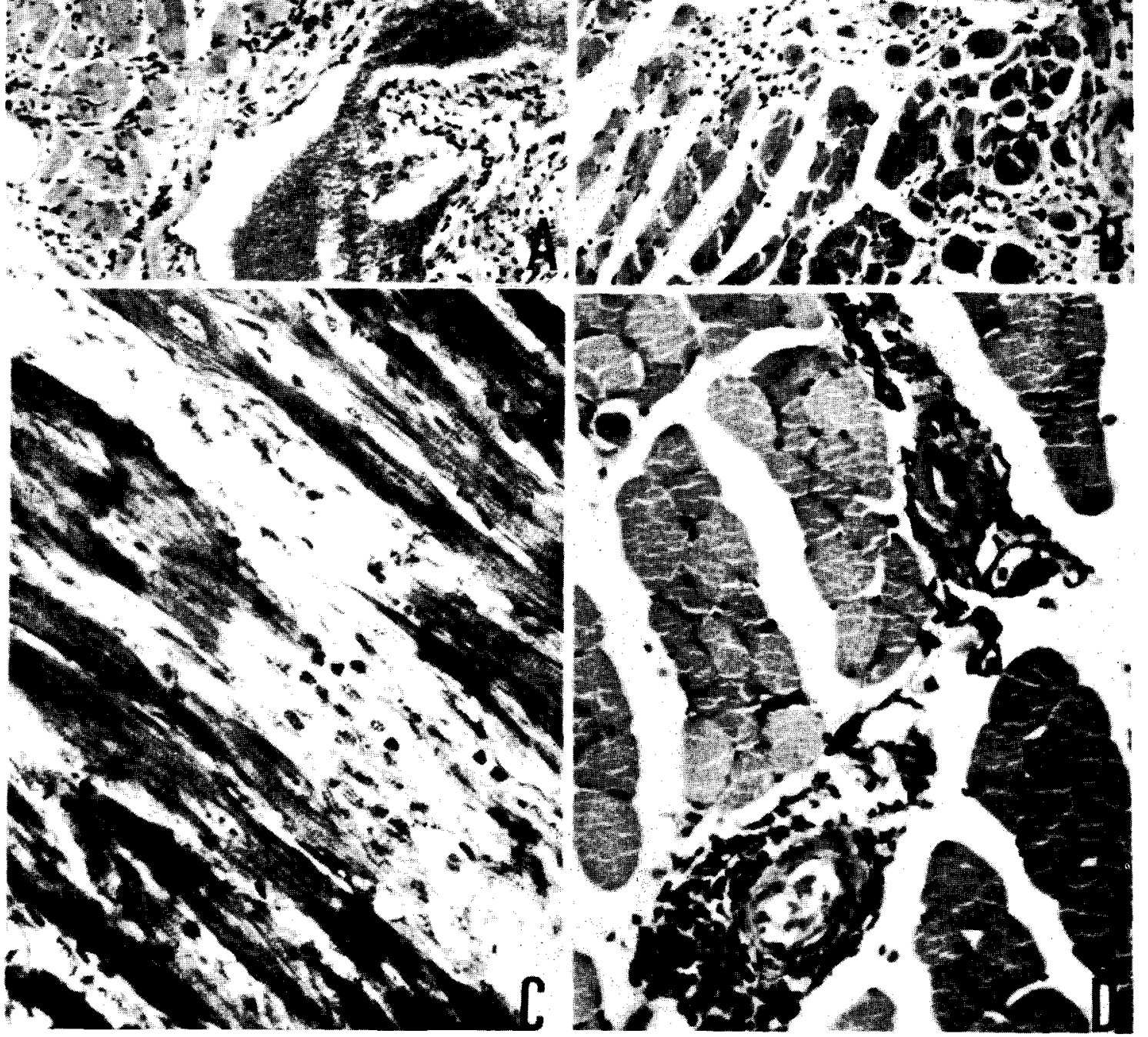

Fig. 3 - A: Strain VL-7, chronic phase, 180 days of infection. Chronic myocarditis with monocuclear infiltrate and mild fibrosis $(200 X)$; B: Strain VL-6, chronic phase, 270 days of infection. Mononuclear inflammatory cells and fibrosis $(200 X)$; C: Strain VL-2, chronic phase, 270 days of infection. Chronic myocarditis. Destruction of heart muscle cells and fibrosis (320X); D: Strain VL-1, chronic phase, 90 days of infection. Skeletal muscle cells. Necrotizing arteritis $(200 X)$. 
and most animals died between 20 to 30 days after infection with parasitemias as high as $2-3 \times 10^{6}$ parasites $/ \mathrm{ml}$.

Typical curves of parasitemia are illustrated in Figure 1.

\section{TISSUE PARASITISEM AND PATHOLOGY AT THE CHRONIC STAGE}

Tissue parasites. From the total of $\mathbf{2 1 2}$ examined animals, intracellular parasites were detected in $42(19.8 \%)$, distributed among 13 of the 17 groups of animals inoculated with the various strains. The presence of tissue parasites in the chronic phase was directly related to the virulence exhibited by the strains in the acute stage of infection: $11.4 \%(14 / 122), 27.2 \%$ $(21 / 77)$ and $53.8 \%(7 / 13)$ of the mice infected respectively with the strains of low, intermediate and high virulence displayed in tracellular parasites, a finding of high significance $(r=0.99$, $\mathrm{p}<0.001$ ). An exception was represented by strain VL-6 which, although of low virulence, induced tissue parasitism in $46 \%$ of the animals. The percentage of animals showing tissue parasites in the chronic phase was rather stable, as follows: 3 months, $22.8 \%$; 6 months, $15.0 \%$; 9 months, $20.0 \%$ and 12 months, $30.8 \%$.

Inflammatory lesions. Infiltrates of inflammatory cells, predominantly mononuclear cells were the most frequent lesions in the heart and skeletal muscle. Practically all infected animals displayed variable degrees of inflammatory lesions in the heart, from small foci to diffuse confluent cell infiltration (Figs. 2 e 3). In general the lesions were more severe in the atria than in the ventricles. The frequency and intensity of the inflammatory lesions were directly related to the virulence of the strain in the acute phase, with the exception of strain VL-6 which was of low virulence but induced a severe chronic myocardiopathy.

A certain stability of the lesions occurred within the period of 3 to 12 months of obser. vation and no tendency to decline or enhancement of the inflammatory process could be observed. Cell infiltration of the intracardiac gangliae of the autonomic nervous system was also often present.

Fibrosis. Fibrosis was detected in mice infected with 10 out of the 17 strains investigated. This lesion occurred in $5.7 \%$ of the 122 anima!s inoculated with the low virulent strains, $11.6 \%$ of 77 infected with the strains of intermediary virulence and $30.8 \%$ of 13 animals harboring the high virulent parasites $(r=0.98$, $p<0.01)$. The fibrosis was progressive and has been found in $0 \%(0 / 79), 7.5 \%(6 / 80), 25.0 \%$ $(10 / 40)$ and $30.8 \%(4 / 13)$ of the mice infected for respectively $3,6,9$ and 12 months ( $r=0.98, p<0.001$ ).

Necrotizing arteritis. This lesion was characterized by infiltration of inflammatory cells in the wall of arteries with necrosis predominantly in the intima and media (Fig. 3). Such lesions were found mostly in skeletal muscle but also in the heart and colon; they were detected in animals inoculated with 13 of the 17 strains and found in 26 out of 212 animals $(12.2 \%)$. The vascular lesions were apparently progressive since they were observed in $1.6 \%$, $20.0 \%, 27.3 \%$ and $45.5 \%$ of the animals sacrificed respectively after $90,180,270$ and 365 days of infection $(r=0.98)$. No correlation could be established between the prevalence of necrotizing arteritis and either inflammatory reaction or strain virulence.

The described lesions were not found in the control animals within the period of observation. No relationship could be established between the pathogenicity of the strains and the clinical forms of patients from whom they had been isolated.

\section{DISCUSSION}

Some requirements for the identification of suitable chronic models for Chagas, disease have been already established and one of them is that the animal should develop lesions which would resemble human pathology ${ }^{15}$. Some observations in the literature suggest that mice might be suitable models for the chronic chagasic myocardiopathy ${ }^{11}$. However, a study of the influence of the natural course of infection of different $T$. cruzi strains in the development of histopathological lesions, mainly in the heart, has not yet apparently been reported. In this paper we studied the role played by newly isolated strains from chronic patients with different clinical forms, presenting variable degrees of virulence, on the pathology of infected mice.

In our study intracellular parasites were detected in striated and smooth muscie cells in about $20 \%$ of the chronically infected animals. The presence of tissue parasitism at the chronic phase was clearly related to the strains virulence 
in the acute phase, an indication that the increased multiplication rate of some $T$. cruzi strains is an intrinsic characteristic which is maintained in both disease stages. Parasites in the heart have been detected in about $50 \%$ of mice inoculated by Federici et al. ${ }^{9}$ and Gonzalez-Cappa et al. ${ }^{10}$ and maintained for over 12 months. Andrade \& Ramalho ${ }^{3}$ found parasites in $30 \%$ of 126 hearts from chronic chagasic patients who died from congestive heart failure. This high figure might suggest a relationship between tissue parasitism (or virulence) and severity of heart lesions.

The two main features of the chronic chagasic myocardiopathy, namely, the inflammatory process and the fibrosis were clearly associated to the virulence of $T$. cruzi strains. On the other hand, fibrosis was related to the intensity of the inflammatory reaction, in accordance with the findings reported by Tafuri ${ }^{17}$. Heart fibrosis in chronically infected mice is apparently a late phenomenon and has been detected only after 6 months infection by Federici et al. ${ }^{9}$. According to Andrade ${ }^{1}$, fibroblastic proliferation was observed in infected mice between 90 - 120 days of infection, whereas fibrosis was present only after 6 months. Our data are in agreement with those previous observations and confirm the progressive characteristic of the fibrotic lesions in the chagasic myocardiopathy ${ }^{2}$.

The possibility that human chronic cardio pathy might in some way be related to the course of infection in the acute phase was recently raised by Dias $^{8}$. In a comprehensive analysis of a prolonged follow-up of acute cases of Chagas' disease the author reported that the prevalence of the chronic cardiopathy in a group of patients who presented severe clinical manifestations in the acute phase was significantly higher $(66.6 \%)$ than in the group with mild symptoms $(7.6 \%)$.

The demonstration that a high percentage of T. cruzi strains isolated from human patients are of low virulence in experimental conditions indicates that more attention should be paid to those populations, which are often neglected because of their difficult adaptation to animal models. There are other evidences that such strains are more representative of the pool of $T$. cruzi populations which circulate in nature. Andrade 1 isolated 15 strains from humans in Bahia, Brazil and reported that 7 were of low virulence, 7 of mild virulence and only 1 was of high virulence. Carneiro et al. ${ }^{7}$ describea that among 11 strains from chronic patients in Bambui, Brazil only 1 was virulent to mice. It should be mentioned that the low virulent strains tend to keep this characteristic in the laboratory regardless of experimental manipulations such as inoculation into baby-mice or $X$-irradiated animals which induce only transient enhancement of parasitemia and mortality ${ }^{16}$.

The vascular lesions (necrotizing arteritis) found in our infected mice were more related to the duration of infection rather than with the strain virulence. The pathogenesis of this vascular damage which has also been described in the human disease ${ }^{6}$ is not clear and has been suggesred to represent a phenomenon of hypersensitivity.

\section{RESUMO}

Camundongos foram inoculados com formas sangülneas de 17 cepas de T. cruzi recentemente isoladas de pacientes chagásicos crônicos e que foram classificadas como de alta, média e baixa virulência através da determinação do período pré-patente, parasitemia e mortalidade na fase aguda da infecção. Cerca de 212 animais inoculados com as diferentes cepas foram estudados após $3,6,9$ e 12 meses de infecção. Na fase crônica da infecção parasitas intracelulares foram observados em $11.0 \%, 27.0 \%$ e $54.0 \%$ dos camundongos inocula. dos respectivamente com as cepas de baixa, média e alta virulência $(r=0.99, \rho<0.001)$. A fibrose cardíaca também esteve relacionada à virulência sendo encontrada em $5.7 \%$, $11.6 \%$ e $30.8 \%$ das mesmas cepas $(r=0.98, p<4.005)$; relação similar foi encontrada entre a intensidade e freqüência do processo inflamatório no coração e a gravidade da infecção aguda. Arterite necrotizante foi detectada em $12.2 \%$ dos animais e esta lesão estava mais relacionada com a duração da infecção que com as características das cepas. Os infiltrados inflamatórios e o parasitismo tissular permaneceram estáveis durante o curso da infecção enquanto que a fibrose foi progressiva. Esses achados sugerem que o camundongo pode reproduzir lesões cardiacas que se assemelham às da cardiopatia chagásica humana e que as lesões dependem da cepa de T. cruzi utilizada. 


\section{REFERÊNCIAS BIBLIOGRÃFICAS}

1. Andrade SG. Caracterização de cepas do Trypanosoma cruzi isoladas no Recôncavo Bahiano (Contribuição ao estudo da patologia geral da doença de Chagas em nosso meio). Thesis, Universidade Federal da Bahia, Salvador, 1973

2. Andrade ZA, Andrade SG. Patologia. In: Brener Z, Andrade ZA (ed) Trypanosoma cruzi e doença de Chagas. Guanabara Koogan, Rio de Janeiro, p 199-248, 1979

3. Andrade ZA, Ramalho LMP. Miocardite chagásica (Estudo morfológico de 38 casos comprovados pelo encontro de parasitos nas secções histológicas). Gazeta Médica da Bahia 66: 55-67, 1966

4. Andrade ZA, Andrade SG. A patologia da doença de Chagas experimental no cão. $\mathrm{Me}$ mórias do Instituto Oswaldo Cruz 75 : 77-96, 1980

5. Brener $Z$. Therapeutic activity and criterion of cure in mice experimentally infected with Trypanosoma cruzi. Revista do Instituto de Medicina Tropical de São Paulo 4: 389-396, 1962

6. Brito $T$, Vasconcelos $E$. Necrotizing arteritis in megaesophagus. Histopathology of ninety one biopsies taken from the cardia. Revista do Instituto de Medicina Tropical de São Paulo 1: 195-206, 1959

7. Carneiro M, Romanha AJ, ChairiE.'Comportamento biológico de amostras do Trypanosoma cruzi. In: Proceedings VIII Reunião Anual sobre Pesquisa Básica em Doença de Chagas, Caxambú, p 37, 1981

8. Dias JCP. Doença de Chagas em Bambuí, Minas Gerais, Brasil. Estudo clínico-epidemiológico a partir da fase aguda, entre 1940 e 1982. Thesis, Universidade Federal de Minas Gerais, Belo Horizonte, 1982

9. Federici EE, Abelman WH, Neva FA. Chronic and progressive myocarditis and myositis in $\mathrm{C} 3 \mathrm{H}$ mice infected with Trypanosoma cruzi. American Journal of Tropical Medicine and Hygiene 13: 272-280, 1964

10. Gonzalez Cappa SM, Chiale P, Del Prado GE, Katzin AM, Martini GW, Isola ED, Orrego LA, Segura EL Aislamento de una cepa de Trypanosoma cruzi de un paciente con miocardiopatia chagásica cronica y su caracterización biológica. Medicina (Buenos Aires) 40: 63-68, 1980

11. Laguens RP, Meckert PC, Gelpi RJ Chronic Chagas' disease in the mouse. I. Electrocardiographic and morphological patterns of the cardiopathy. Medicina (Buenos Aires) 41: $35 \cdot 39,1981$

12. Miles MA, Toyé PJ, Oswald SC, Godfrey DG. The identification by isoenzyme patterns of two distinct strain-groups of Trypanosoma cruzi, circulating independently in a rural area of Brazil. Transactions of the Royal Society of Tropical Medicine and Hygiene 71: 217-225, 1977

13. Ramirez LE, Vargas $M$, Brener $Z$. Histopathology of rabbits chronically infected with Trypanosoma cruzi. In: Proceedings VIII Reunião Anual sobre Pesquisa Básica em Doença de Chagas, Caxambu, p 37. 1982

14. Romanha AJ. Heterogeneidade enzimática do Trypanosoma cruzi. Thesis, Universidade Federal de Minas Gerais, Belo Horizonte, 1982

15. Schlemper Jr BR. Caracterização de cepas do Trypanosoma cruzi isoladas de pacientes com diferentes formas clínicas da doença de Chagas. Thesis, Universidade Federal do Rio de Janeiro, Rio de Janeiro, 1982

16. Schlemper Jr BR, Brener Z. Comparative study of Trypanosoma cruzi strains from two geographic areas. I. Isolation and adaptation to mice. In: Proceedings Congresso Internacional de Doença de Chagas, Rio de Janeiro, p 34, 1979

17. Tafuri WL. Microscopia eletrônica do mio cárdio na fase aguda da tripanosomiase aguda experimental. Revista do Instituto de Medicina Tropical de São Paulo 11: 151 164,1969

18. Teixeira ARL, Teixeira ML, Santos Buch CA. The immunology of experimental Chagas' disease. IV. Production of lesions in rabbits similar to those of chronic Chagas' disease in man. American Journal of Pathology 80: 163-180, 1975

19. Zeledon R, Alvarenga NJ, Schosinsky K. Ecology of Trypanosoma cruzi in the insect vector. In: Chagas' disease. Pan American Health Organization, Scientific Publication No 347, p 59-70. Washington, 1977 